\title{
Consumer Perceptions towards Dairy Products: Effects of Mass Media
}

\author{
Gülseren Şendur Atabek \\ Yasar University, Faculty of Communication, Department of New Media and Communication, \\ Izmir, TURKEY \\ (D) 0000-0001-9118-2329 \\ Ümit Atabek \\ Yasar University, Faculty of Communication, Department of Public Relations and Advertising, \\ Izmir, TURKEY \\ (D) 0000-0002-7573-0839 \\ umit.atabek@yasar.edu.tr
}

\author{
ARTICLE INFO \\ Received: 11 January 2019 \\ Accepted: 21 February 2019 \\ Published: 8 May 2019 \\ DOI: https://doi.org/10.29333/ojcmt/5762 \\ ABSTRACT
}

Using the information from mass media, consumers develop their perceptions towards dairy products. This article examines how these perceptions are developed. Based on a mixed design, our research has three consecutive data collection phases. The first phase is a quantitative content analysis of four major Turkish newspapers, three popular Turkish television health shows and Turkish internet content on dairy products. Second phase is designed to collect qualitative data from three focus groups in order to reveal what kinds of perceptions are developed about milk, cheese and yogurt and how the consumers verbally express them. Findings from these two phases are used to develop a questionnaire, which is applied to a sample of 733 urban consumers, for the quantitative measurement of these perceptions. Findings reveal that mass media disseminates huge amount of information to which consumers are exposed. Consumers admit that their decisions were usually affected by such information. Survey results showed that dairy consumers tend to trust more in the positive claims than the negative ones. Consumers mostly develop perceptions regardless of their socio-demographic differences due to the mainstreaming effect of mass media. However, a cluster analysis showed that younger, more educated, wealthier and regular diary consumers have lower levels of negative perceptions about milk, cheese and yogurt. On the other hand, consumers with more trust in media and readiness to share media information have higher levels of positive perceptions about milk and yogurt.

Keywords: mass media effects, trust in media, consumer perceptions, dairy products

\section{INTRODUCTION}

Consumers develop negative and positive perceptions about food products through a quite complex process. These perceptions affect the attitudes and behaviors of consumers. Purchasing decisions of consumers are usually based on these perceptions. This process is particularly critical for dairy products for which the consumers' perceptions may change rather swiftly. 
Mass media information plays a crucial role on consumers' perception. In modern societies, a complex and intricate media system vigorously and stealthily mediates certain social issues. Although media is an indispensable partner for marketers, they must carefully craft their position with media which usually complicates consumer perceptions. Furthermore, several civil society actors also participate in shaping public opinion on critical health and food issues through media channels. Therefore, it is important to examine and analyze media information towards food consumers.

This article provides such an analysis of mass media information on milk, cheese and yogurt. Media information is one of the essential contributing factors to consumers' negative and positive perceptions. Consumers' perceptions about food products are mainly based on media information in modern societies that are typically exposed to extensive mass media content. This article also provides a further analysis of how strong these perceptions are and how they are mediated through mass media information.

\section{LITERATURE REVIEW}

Perception is the initial phase of long and complex successive processes. Perceptions shape the attitudes and opinions, which shape behaviors, the last phase before the human action. In their theory of reasoned action, Fishbein and Ajzen (2010) described that human behavior can be predicted by intentions which are controlled by perceptions and attitudes. Perception can be defined as "the organization, identification, and interpretation of sensory information in order to represent and understand the environment" (Schacter, Gilbert \& Wegner, 2011, p. 90). It is a cognitive process based on sensations. However, the sensation and cognition do not function merely physically or anatomically; rather they are realized in a social context. Conceptualizing, explaining and managing the perceptions of consumers are very important for marketing. Starting from the classical Howard-Sheth (1969) model, consumers' perceptions have always been considered as an important element in marketing. This model emphasizes perception, learning and attitude as the three key variables of consumer buying behavior (Sherlekar, Prasad \& Victor, 2010). Perceptions influence the value of the product to you, your decision to buy, and whom to buy from. Dairy producers try to adjust their products accordingly with their customers' perceptions (Peng, West \& Wang, 2006). Hsu and Liu (2000) suggest that advertisers must consider dairy consumers' perceptions when designing their advertisements.

Marketing tries to create the perception of a positive difference that will cause us to consider buying it instead of the competing product (Zimmerman, 2008). Some marketers refer to perception as an additional ingredient in marketing mix (Hundekar, Appannaiah \& Reddy, 2010). Most of the marketing activities are directly related to consumer perceptions. Even the price can be set in compliance with consumer's perception of value. 'Buyer based pricing' or 'perceived value pricing' is an example for such pricing on the product's perceived value; buyers' perception of value not the sellers' cost, is the key to pricing (Kortge \& Okonkwo, 1993; Ramachandra, Chandrashekara \& Shivakumar, 2010; Monroe 2012). In a similar fashion, overall corporate image is strongly linked to perceptions of stakeholders and in this venue, even corporate annual reports can be used as a tool of "perception engineering" (Courtis, 2002, p. 449). Quality perception functions quite in a similar way; the quality of a product is usually the perceived quality of that product. Based on this point, a quality perception model is developed in order to minimize the difference between the quality defined by the producer and the quality perceived by the consumer (Ophuis \& Van Trijp, 1995). This model suggests that the producers should analyze the perceptions of consumers in order to improve their products. Unsatisfied 
consumers tend easily to switch to other brands; and accordingly the marketers should pay special attention to consumer perceptions in order to survive in a competitive market. In their research on the differences between the perceptions of consumers and executives of a milk brand, Kumar and Gogoi (2009) warn that if the company fails to react accordingly, the unsatisfied consumers may shift to other alternative brands. Such evidence implies that there exists a certain association between consumer perceptions and consumer loyalty.

Marketing of dairy products in particular is highly sensitive to consumer perceptions. Consumers in modern world have become more concerned about health and food issues (Morrison, 2008). In developed countries, factors such as care for healthiness and environmental issues play an increasingly important role in food choice (Gracia \& Albisu, 2001). For example, consumers' top three food preference factors in UK are 'good taste', 'freshness' and 'good for health' (Weatherell, Tregear, \& Allinson, 2003). Accordingly, media disseminates increasingly more health and food related content in order to comply with the audience demand. Barker, McNeir, Sameer and Russle (2014) report a significant increase in nutrition and slimming related content in UK women's magazines from 1950 to 1998. Media channels are usually the most important information sources for large masses. Yadavalli and Jones (2014) have shown how consumers may react drastically to media reports about food scare events. American Dietetic Association 2011 annual survey revealed that top three information sources on food consumption are television (67\%), magazines (41\%) and internet (40\%) (ADA, 2011). Turkish consumers are no exception concerning the importance of television as an information source for food security (Koç \& Ceylan, 2009).

Dairy products consumption in Turkey is fairly high. In parallel to this, Turkey has a vivid dairy industry, which aimed at essentially growing urban consumer markets (Bor, 2014; Terin, Bilgiç, Güler \& Yavuz, 2014). Milk is considered as a strategically important commodity in Turkey (Günden, Bilgic, Miran \& Karli 2011). Due to economies of scale in this growing market, Turkish dairy processing firms continue to be profitable (Tekgüç, 2013). According to State Institute of Statistics, in 2017 total raw milk production almost exceeds 20 million tons (TÜİK, 2018a) and İzmir province takes the second place in Turkey with nearly 1 million ton production (TÜİK, 2018b).

Our research is expected to provide insights for this steadily growing market in terms of consumers' perceptions as they developed through mass media. We aim to explore the media contents that are available to consumers in developing their perceptions about dairy products. We try to explore how and to what extend this media information mediate the consumers' perceptions. Mass media has strong impacts on the formation of consumer perceptions and behaviors as detailed by general agenda setting theory. The two prominent figures of this theory, McCombs and Shaw (1972) emphasize that media content shapes the reality perceived by the audience who not only learn about a given issue, but also how much importance to attach to that issue. Agenda setting theory implies that mass media has the ability to influence the importance placed on the topics of the public agenda. Mass media tells people what to think about, by disseminating information on certain issues. Agenda setting theory further suggests a second-level agenda-setting: attribute agenda setting, which is about how to process the information that we get from mass media. In this context, audience perceptions are usually manufactured by mass media by putting forward certain issues. In order to comprehend this process of perception formation, we raise our first research question $(R Q 1)$ : Which dairy related issues are developed and disseminated by mass media? Secondly, in order to analyze the process, we 
need to examine how these perceptions are verbally formulated by the consumers themselves. Therefore our second research question can be formulated as (RQ2): Which mediated perceptions towards dairy products are prevalent among consumers and how are they verbally expressed? Thirdly, we need to measure how these perceptions are observed in the general consumer population. This brings forward our third research question (RQ3): How strong are these mediated consumer perceptions? Finally, knowing that perceptions are usually moderated by several characteristics of the perceiver (Bordens \& Horowitz, 2000), we need to test if negative and positive perceptions about dairy products change in terms of several consumer traits. In this context, we formulate two hypotheses to test: $\left(H_{1}\right)$ Younger, more educated, wealthier and regular diary consumers have lower levels of negative perceptions about dairy products, and $\left(H_{2}\right)$ Consumers with more media trust and readiness to share such information have higher levels of positive perceptions about dairy products.

\section{METHODOLOGY}

This research has a design of three consecutive data collection phases. The first phase is a quantitative content analysis (QCA) of four major Turkish newspapers, three popular Turkish television health programs and Turkish web pages on milk, cheese and yogurt in 2013. This media content analysis is about our first research question (RQ1). In order to maximize the representative diversity, purposive sampling technique was applied and four newspapers were selected to represent Turkish national press: Hürriyet (politically center, mainstream), Posta (politically center, yellow press), Zaman (politically right wing) and Cumhuriyet (politically left wing). All journalistic textual content types, namely news stories, articles, interviews etc. were taken into consideration for the analysis. Unit of analysis was each 'mention' of milk, cheese and yogurt in these texts. All together 976 newspaper mentions were found about milk, cheese and yogurt. Additionally, three TV health shows were chosen for the analysis: Canım Doktor (My Sweet Doctor), Doktorum (My Doctor) and Reçetesiz Hayat (Life without Prescriptions). These shows were broadcast weekly in three mainstream Turkish television channels, also selected with purposive sampling. 106 mentions were found about milk, cheese and yogurt in these shows over one year. Finally, a search on internet in Turkish dairy web pages generated 178 mentions of milk, cheese and yogurt consumption and production categories. The total number of dairy product mentions in all mass media was 1260 .

The contents of these 1260 total mentions were analyzed quantitatively. Main categories of analysis were milk, cheese and yogurt. Sub-categories were developed from a grounded theory perspective. The grounded theory approach is a methodology where conceptualization of data through coding is the foundation (Glaser 2004). Each mention in the sampled texts was coded according to their topics to fit into one of the sub-categories developed through grounded theory perspective. All newspaper content coding was performed by 4 coders into SPSS software. In order to improve inter-coder reliability for newspaper texts, 4 coders each examined selected newspaper texts individually; and later they re-examined them as a group to discuss and settle the coding problems. Coder group discussion technique as suggested by Hruschka et al. (2004) was applied to all problematic issues during whole coding process of newspaper texts. Television and internet contents were coded by a single coder; therefore no extra measures were needed for inter-coder homogeneity.

The second phase was designed to collect qualitative data from three focus groups in order to comprehend the perceptions the consumers developed about milk, cheese and 
Online Journal of Communication and Media Technologies, 2019

Table 1. Socio-demographic distribution of focus group members $(N=18)$

\begin{tabular}{lccccccc}
\hline Gender & $\mathbf{n}$ & Education & $\mathbf{n}$ & Income & $\mathbf{n}$ & Age & $\mathbf{n}$ \\
\hline Male & 7 & Primary & 1 & Poor & 0 & Young & 5 \\
Female & 11 & Secondary & 1 & Lower middle & 2 & Middle age & 10 \\
Marital status & $\mathbf{n}$ & High school & 4 & Middle class & 8 & Elderly & 3 \\
Married & 12 & University & 6 & Upper middle & 7 & & \\
Single & 6 & Graduate degree & 6 & High income & 1 & & \\
\hline
\end{tabular}

Table 2. Socio-demographic distribution of survey participants $(N=733)$

\begin{tabular}{lccccccc}
\hline Gender & $\mathbf{n}$ & Education & $\mathbf{N}$ & Income & N & Age & n \\
\hline Male & 362 & Primary & 16 & Poor & 133 & Young & 211 \\
Female & 371 & Secondary & 155 & Lower middle & 150 & Middle age & 391 \\
Marital status & $\mathbf{n}$ & High school & 188 & Middle class & 228 & Elderly & 131 \\
Married & 464 & University & 313 & Upper middle & 138 & Mean age & 39.0 \\
Single & 266 & Graduate degree & 59 & High income & 84 & & \\
\hline
\end{tabular}

yogurt; and how they verbally expressed these perceptions. The focus group data is collected in relation to our second research question $(R Q 2)$. Three focus groups were formed each with 6 persons from different socio-demographic status (18 persons in total). The socio-demographic distribution of focus group members is shown in Table 1. The transcripts of these three focus group sessions were produced in text file format and imported into qualitative analysis software Nvivo. Only one coder coded all the transcribed texts, therefore no inter-coder reliability measures were needed. Word similarity checks for three focus groups transcribed texts showed that they are reasonably similar to each other (Pearson correlation coefficients are 0,68 for group 2 and 1; 0,67 for group 3 and 1; 0,53 for group 3 and 2).

The findings from the first and the second phases are then used to develop a questionnaire to measure the level of these perceptions, and this is about our third research question (RQ3). Apart from socio-demographic, dairy product consumption level and media usage habits questions, the questionnaire had 35 perception statements. These were designed in 5-point Likert-like scale statements in order to measure the strength of the perceptions explored in media analysis and focus groups. The sample size $(N=733)$ was expected to provide a $99 \%$ confidence level and \pm 5 margin of error level. The questionnaire was applied face-to-face to sampled urban population in Izmir, Turkey. Stratified sampling technique was preferred for a more representative sample. The sociodemographic distribution of survey participants is shown in Table 2.

Finally, we assumed that dairy consumption frequency together with socio-economic variables may influence perceptions about dairy products. In this respect, consumers are grouped into two clusters based on their age, education, income and frequency of dairy consumption. Then, we hypothesized if younger, more educated, wealthier and regular diary consumers have less negative perceptions $\left(H_{1)}\right.$. Additionally, we assumed that trust in media for nutrition and health information, and readiness to share this information with others may be related to perceptions about dairy products. Consumers are again grouped into two clusters, this time based on their trust on media for nutrition and health information and their readiness to share such information. Then we hypothesized if consumers with more trust in media and readiness to share media information have higher levels of positive perceptions about dairy products $\left(H_{2)}\right.$.

\section{FINDINGS AND DISCUSSION}

Media content analysis revealed that Turkish mass media channels cover fairly numerous issues on milk, cheese and yogurt consumption and production. In relation with 
Table 3. Most frequently mentioned dairy topics in Turkish media

\begin{tabular}{|c|c|c|c|c|c|}
\hline $\begin{array}{l}\text { Milk } \\
\text { consumption }\end{array}$ & Milk production & $\begin{array}{c}\text { Cheese } \\
\text { consumption }\end{array}$ & $\begin{array}{c}\text { Cheese } \\
\text { production }\end{array}$ & $\begin{array}{c}\text { Yogurt } \\
\text { consumption }\end{array}$ & $\begin{array}{r}\text { Yo } \\
\text { prod }\end{array}$ \\
\hline $\begin{array}{l}\text { Source of calcium } \\
\text { (85) }\end{array}$ & $\begin{array}{c}\text { UHT- } \\
\text { Pasteurization }\end{array}$ & $\begin{array}{c}\text { Taste-gourmet } \\
\text { (36) }\end{array}$ & Add & $\begin{array}{c}\text { Source of calcium } \\
\text { (31) }\end{array}$ & $\begin{array}{c}\text { Additives } \\
(8)\end{array}$ \\
\hline Fat i & $\begin{array}{l}\text { Antibiotic in milk } \\
\text { (4) }\end{array}$ & Fat i & Brucellosis (2) & $\mathrm{Fa}$ & $\begin{array}{l}\text { Natural } \\
\text { Yeast (4) }\end{array}$ \\
\hline $\begin{array}{l}\text { Source of protei } \\
\text { 37) }\end{array}$ & $\begin{array}{c}\text { Animal } \\
\text { nourishment (4) }\end{array}$ & $\begin{array}{c}\text { Source of } \\
\text { calcium (21) }\end{array}$ & $\begin{array}{l}\text { Re-melting after } \\
\text { expiration date }(1)\end{array}$ & $\begin{array}{l}\text { Regulating blood } \\
\text { glucose }(28)\end{array}$ & $\begin{array}{c}\text { Packaging } \\
(3)\end{array}$ \\
\hline
\end{tabular}

Table 4. Information sources on dairy related content in Turkish media

\begin{tabular}{lc}
\hline Source & $\mathbf{\%}$ \\
\hline Medical Doctor & 30.6 \\
Dietician & 21.4 \\
Unknown & 15.0 \\
Industry Spokesperson & 9.7 \\
Public Authority & 7.3 \\
Food Engineer & 3.0 \\
Scientist & 2.3 \\
Expert & 1.5 \\
Other & 9.3 \\
Total & $\mathbf{1 0 0 . 0}$ \\
\hline
\end{tabular}

Table 5. Most frequently mentioned dairy product topics in focus groups

\begin{tabular}{|c|c|c|c|c|c|}
\hline $\begin{array}{l}\text { Milk } \\
\text { consumption }\end{array}$ & $\begin{array}{c}\text { Milk } \\
\text { production }\end{array}$ & $\begin{array}{c}\text { Cheese } \\
\text { consumption }\end{array}$ & $\begin{array}{c}\text { Cheese } \\
\text { production }\end{array}$ & $\begin{array}{c}\text { Yogurt } \\
\text { consumption }\end{array}$ & $\begin{array}{c}\text { Yogurt } \\
\text { production }\end{array}$ \\
\hline Goat 1 & $\begin{array}{c}\text { UHT/Pasteuriza } \\
\text { tion (16) }\end{array}$ & $\begin{array}{l}\text { Taste-gourmet } \\
\text { (16) }\end{array}$ & $\Delta d d$ & Dioest & (10) \\
\hline Packaging (23) & $\underset{\text { nourishment (7) }}{\text { Animal }}$ & $\begin{array}{c}\text { Bone } \\
\text { development (11) }\end{array}$ & $\begin{array}{l}\text { Re-melting after } \\
\text { expiration date (4) }\end{array}$ & $\begin{array}{l}\text { Improving face } \\
\text { skin beauty ( } 7 \text { ) }\end{array}$ & Pack: \\
\hline $\begin{array}{l}\text { Bone } \\
\text { development (15) }\end{array}$ & $\begin{array}{c}\text { Animal } \\
\text { husbandry (2) }\end{array}$ & Cheese whey (11) & Bru & $\begin{array}{c}\text { Cause for } \\
\text { ferrous } \\
\text { deficiency (5) }\end{array}$ & $\begin{array}{c}\text { Celluloid } \\
\text { additives for } \\
\text { extra cream (4) }\end{array}$ \\
\hline
\end{tabular}

$R Q 1$, Table 3 shows the top issues on dairy consumption and production. Most of the media mentions were on milk consumption and productions issues (880) while yogurt (412) and cheese (371) mentions were relatively low.

Table 4 shows the distribution of information sources of dairy topics in Turkish print media in general. The results are not much different from the results of a previous retrospective research on health news (Atabek, Atabek \& Bilge, 2013, p. 125) for the mainstream daily Hürriyet between 1970 and 2010.

We used Nvivo qualitative data analysis software for the analysis of focus group transcriptions and it is found that closely similar diary related issues were the concerns of the participants. In relation with $R Q 2$, Table 5 shows top issues mentioned by 18 participants. Additionally, we used Yoshikoder open source software for a dictionary based word count analysis on focus group transcriptions (Lowe, 2015). This analysis revealed that participants mentioned milk most $(n=764)$ while yogurt $(n=428)$ and cheese $(n=407)$ received relatively low mentions, just as similar to the numbers of mentions in media. Therefore, focus group participants' narrations are typically in compliance with what they selectively learn from mass media.

These findings demonstrate that dairy issues mediated through mass media channels develop the consumers' agenda to a large extend in compliance with the agenda setting theory of McCombs and Shaw (1972). However, media agenda setting power is not always strong for every topic and in all socio-cultural environments. For instance, political agenda setting power of media is debated (Walgrave, Soroka \& Nuytemans, 2008). 
Political agenda setting power of Turkish media is also questioned (Batmaz, 2011). Nevertheless, Turkish media is generally believed to have a certain degree of agenda setting power on domestic and international issues (Irvan, 1997; Yüksel, 1999). The findings of our study are yet another instance for agenda setting power of Turkish media on food and health issues. Both media content and focus group analyses reveal that consumers are exposed a large amount of media information which is effective in developing their perceptions.

Gender appeared to be an important parameter on perceptions of focus group participants. Nvivo matrix coding query for "gender" and "face skin beauty" revealed that such issues were mostly female (11 mentions) concerns than male (4 mentions). A married, middle aged and middle class man referred milk and skin relation as "a feminine issue". A single, middle aged and upper-middle class woman described her trust with yogurt's skin beauty effect as "you can apply yogurt as a cream for the face". Another matrix coding query for "gender" and "cheese taste-gourmet" showed that males (10 mentions) were more interested in cheese taste-gourmet value than females (6 mentions). A single, elderly and high income man defined cheese as "a cultural issue". A married, middle-aged and upper-middle class man claimed he would taste different types of cheeses "even if they were unhealthy". Additionally, education level is an important factor for food quality concerns of focus group participants. More educated participants of the focus groups claimed that they usually pay attention to the labels of the dairy products they purchase. This is in compliance with Gezmen-Karadağ and Türközü (2018) who report that Turkish educated and high income urban consumers paid more attention to nutrition labels for dairy products.

The most mentioned information source for food consumption by the focus group participants is television, mentioned 66 times. This is followed by internet (34 times), newspaper (22 times) and radio (5 times). For the survey participants, television (26.8\%) is also the most important information source for food consumption, followed by internet (23.3\%), friends and family members (21.5\%), and newspaper (15.1\%). Moreover, when distributed against age groups, television becomes the number one media for middle age $(41.4 \%)$ and elderly $(55.5 \%)$ groups while it is the internet for young people $(59.6 \%)$. University and higher educated female members of focus group reported that they don't use television as an information source much; however their mothers who watch television extensively echoes the televised information to them so that they are inevitably affected. On the other hand, survey respondents admit "friends and family members" as another important source of food information (21.5\%). Survey respondents mostly trust to the media channels which they preferred; $61.7 \%$ of respondents admit that they have confidence in the information from their preferred media channels for nutrition and health information. As much as $75.8 \%$ of survey participants said they habitually share this information with friends. These findings are similar with Yüksel, Kaya, Koçak and Aydin (2013); they found that very small number of people claimed they never trust in media for health issues and they always share the information they learn from media with others. All these findings describe a quite an important level of media effect on food and health information.

The questionnaire had 35 perception statements quantified in 5-point Likert-like scale. The perception statements were verbalized in compliance with the findings of media content analysis and focus group mentions. In relation with $R Q 3$, Table 6 shows mean scores and standard deviation values of the respondents' on perception statements for milk, cheese and yogurt. As can be seen from the table, the highest mean scores were 


\begin{tabular}{|c|c|c|c|}
\hline & Milk Statements & Mean & $S D$ \\
\hline 1 & Milk in glass bottle is healthier & 4.27 & 0.799 \\
\hline 2 & Milk prevents bone deformation & 4.07 & 0.725 \\
\hline 3 & Regular milk consumption promotes dental health & 4.02 & 0.740 \\
\hline 4 & Regular milk consumption compensates calcium shortage & 3.85 & 0.916 \\
\hline 5 & Goat milk is healthier than cow milk & 3.80 & 0.905 \\
\hline 6 & Milk from antibiotic treated cows is dangerous to health & 3.79 & 1.452 \\
\hline 7 & Milk from unnaturally nourished cows is not good for health & 3.77 & 0.922 \\
\hline 8 & Packed milk is healthier than open milk & 3.64 & 1.123 \\
\hline 9 & Milk causes digestive problems and gas & 3.57 & 1.049 \\
\hline 10 & UHT reduces nutritional value of long life milk & 3.50 & 1.006 \\
\hline 11 & Milk consumption is healthier for children than adults & 3.28 & 1.188 \\
\hline 12 & Fatty milk causes cholesterol & 3.17 & 1.018 \\
\hline 13 & Pasteurization reduces nutritional value of daily milk & 3.08 & 1.093 \\
\hline 14 & Semi-fat and fatless milk is healthier & 3.07 & 1.092 \\
\hline 15 & Donkey milk is more useful than cow milk & 3.01 & 1.099 \\
\hline \multirow[t]{2}{*}{16} & Milk causes allergy in infants & 2.91 & 1.058 \\
\hline & Cheese Statements & Mean & $S D$ \\
\hline 17 & Cheese is rich in protein & 4.02 & 0.700 \\
\hline 18 & Cheese with higher salt ratio is dangerous to health & 3.91 & 0.957 \\
\hline 19 & $\begin{array}{c}\text { Unpacked and unbranded cheese contains additives such as potato, margarine, } \\
\text { vegetable oil etc. }\end{array}$ & 3.89 & 0.839 \\
\hline 20 & I consume cheese for its gourmet value (taste) & 3.57 & 1.265 \\
\hline 21 & Cheese with less fat is healthier & 3.35 & 1.038 \\
\hline 22 & Unpacked cheese has brucellosis risk & 3.77 & 0.817 \\
\hline \multirow[t]{2}{*}{23} & Moldy cheese can cause cancer & 3.00 & 1.080 \\
\hline & Yogurt Statements & Mean & $S D$ \\
\hline 24 & Yogurt in glass cup is healthier than yogurt in plastic cup & 4.32 & 0.675 \\
\hline 25 & Packed yogurt includes additives to extend shelf life & 4.30 & 0.816 \\
\hline 26 & Yogurt in ceramic cup is healthier than in plastic cup & 4.17 & 0.847 \\
\hline 27 & Homemade yogurt is more delicious than industrial yogurt & 4.08 & 1.165 \\
\hline 28 & Yogurt helps prevent bone deformation & 4.07 & 0.668 \\
\hline 29 & Yogurt helps digestion & 4.05 & 0.643 \\
\hline 30 & Yogurt is good for skin health & 4.03 & 0.739 \\
\hline 31 & Regular yogurt consumption extends lifespan & 3.81 & 0.825 \\
\hline 32 & Regular yogurt consumption is preventative against cancer & 3.65 & 0.837 \\
\hline 33 & Yogurt helps balance blood sugar & 3.61 & 0.746 \\
\hline 34 & Packed yogurt includes additives such as gelatine and celluloid & 3.60 & 0.909 \\
\hline 35 & Semi-fat and fatless yogurt is healthier & 3.11 & 1.050 \\
\hline
\end{tabular}

mostly on positive perceptions on dairy products (i.e. glass and ceramic packaging; delicious taste; good for skin health; protein rich; teeth health; calcium help etc.). Lowest perception levels were on two negative issues: "Milk causes allergy in infants" $(M=2.91)$ and "Moldy cheese can cause cancer" $(M=3.00)$. Except for the "additives to extend shelf life", perceptions on yogurt are comparatively more positive. From these findings, we may claim that positive information disseminated by media has stronger impacts on consumer's perceptions.

Mean perception levels for statements "Milk from antibiotic treated cows is dangerous to health" $(M=3.79)$ and "Milk from unnaturally nourished cows is not good for health" $(M=3.77)$ show that Turkish consumers have moderately high concerns on husbandry nourishment. Millar, Tomkins, White and Mepham (2002) draw our attention to the fact that media information makes the public more concerned about certain diary technologies such as bovine somatotrophin and automated milking systems. Paraffin, Zindove and Chimonyo (2017) showed that urban consumers who have better access to food safety information through media, concern more on traceability than non-urban consumers do. Similarly, Turkish urban consumers were also found to be concerned with hygiene and food security issues (Uysal, Miran, Bektaş \& Günden, 2006). Uçar, Özdoğan and Özfer 
Özçelik (2012) found that food hygiene concerns increase with higher education levels. Ates and Ceylan (2010) also report that milk freshness and packaging were important factors for urban consumers with secondary and above level education, and with high level income. More recently, Konar et al. (2014) also found similar results that urban consumers from high socio-economic status group are more informed about the health risks of street (open) milk. Likewise, our results showed that mass media information increases the Turkish consumers' awareness for certain animal nourishment techniques.

When Spearman's rank correlation coefficient is calculated for education and perception levels, it is found that certain negative perceptions slightly decrease when education level increase: "Fatty milk causes cholesterol" $\left(r_{s}=-0.162, p=.01\right)$; "Milk causes digestive problems and gas" $\left(r_{s}=-0.153, p=.01\right)$; "UHT reduces nutritional value of long life milk" $\left(r_{s}=-0.113, p=.01\right)$; "Pasteurization reduces nutritional value of daily milk" $\left(r_{s}=\right.$ $0.144, p=.01)$; "Moldy cheese can cause cancer" $\left(r_{s}=-0.255, p=.01\right)$. Additionally, similar with the results of Tiryaki and Akbay (2010), and Hatirli, Ozkan and Aktas (2004), education level is also found slightly effective on preferring processed milk: "Packed milk is healthier than open milk" $\left(r_{s}=-0.116, p=.01\right)$. Other than these perception statements age, education and household income did not have much effects on consumers' perceptions. These findings are similar with Bus and Worsley's (2003) research on Australian milk consumers; they observed little variations on perceptions which can be explained by socio-demographic variables. Therefore, we can argue that mass media effectively mediates all these issues to the general public, regardless of socio-demographic differences. This may be attributed to the "mainstreaming effect of mass media" on consumer's perceptions on dairy products. Mainstreaming is a concept developed for television viewership; heavy television viewers from different groups develop a similar outlook through blurring, blending, and bending processes (Gerbner, Gross, Morgan \& Signorielli, 1980; Shanahan \& Morgan, 2003). Heavy exposure to mass media may override individual and group differences, and thus dairy consumers' perceptions diverge less.

It is also found that gender had a limited effect on perceptions. Mann-Whitney U tests revealed that females had stronger perceptions than men for statements "Milk causes allergy in infants" ( $z=-4.363, p=.01)$ and "Yogurt is good for skin health" $(z=-5.219, p=.01)$ while females had weaker perceptions for statement "Milk consumption is healthier for children than adults" $(z=-3.879, p=.01)$. It is also found that marital status had impact on four perception statements: married people have stronger perceptions for "Goat milk is healthier than cow milk" $(z=-4.692, p=.01)$; "Milk causes allergy in infants" $(z=-3.316$, $p=.01)$; "Cheese with higher salt ratio is dangerous to health" $(z=-3.594, p=.01)$ and "Homemade yogurt is more delicious than industrial yogurt" $(z=-3.184, p=.01)$. It is important to note that perceptions on the nutritional value of goat milk and donkey milk has a mild positive correlation $\left(r_{s}=0.358, p=.01\right)$; additionally, they both have slight positive correlations with age $\left(r_{s}=0.189, p=.001\right.$ and $\left.r_{s}=0.193, p=.001\right)$. Perceptions on homemade yogurt's deliciousness had also a slight positive correlation with age $\left(r_{s}=0.219\right.$, $p=.01)$ and a slight negative correlation with education $\left(r_{s}=-0.242, p=.01\right)$ and household income $\left(r_{s}=-0.103, p=.01\right)$. These findings, which are quite similar to those of Ates and Ceylan (2010), may be interpreted in such a way that older, married, poorer and less educated people prefer to consume homemade yogurt more as a traditional taste.

Finally, in order to test our first hypothesis $H_{1}$, surveyed consumers are grouped into two clusters using k-means clustering technique. K-means is a simple, robust, efficient algorithm for clustering a wide variety of data, and its roots can be traced back to the 
Table 7. Mean, $\mathrm{Z}$ and $\mathrm{p}$ values of negative perception items for dairy products

\begin{tabular}{lcccc}
\hline Perceptions & Mean (Group 1) & Mean (Group 2) & $\boldsymbol{Z}$ & $\boldsymbol{p}$ \\
\hline Milk negative perception items (6, 7, 9, 10, 13, 16) & 23.27 & 24.40 & -3.921 & .000 \\
Cheese negative perception items (18, 22, 23) & 14.31 & 14.81 & -2.893 & .004 \\
Yogurt negative perception items (25, 34) & 7.78 & 8.03 & -2.498 & .012 \\
\hline
\end{tabular}

Table 8. Mean, $\mathrm{Z}$ and $\mathrm{p}$ values of positive perception items for dairy products

\begin{tabular}{lcccc}
\hline Perceptions & Mean (Group 1) & Mean (Group 2) & $\boldsymbol{Z}$ & $\boldsymbol{p}$ \\
\hline Milk positive perception items (2, 3, 4) & 12.08 & 11.62 & -2.680 & .007 \\
Cheese positive perception item (17) & 4.04 & 3.95 & -1.234 & .217 \\
Yogurt negative perception items (28, 29, 30, 31, & 23.43 & 22.88 & \multirow{2}{*}{-2.498} & .029 \\
$32)$ & & & \\
\hline
\end{tabular}

middle of the last century (Wu, 2012). Cluster analysis of our data yielded two clusters of consumers: Group 1 included younger, more educated, wealthier consumers with higher dairy consumption levels while Group 2 included older, less educated, poorer consumers with lower diary food consumption level. ANOVA statistics between standardized $Z$ scores of age, education level, household income and diary consumption level of the groups were all significantly different $(\mathrm{p}<0.01)$ after iterating 27 times. Table 7 shows the differences of means between the groups and Mann-Whitney $U$ tests results for the negative perception item responses summed for milk (items $6,7,9,10,13,16$ ), cheese (items 18, 22,23 ) and yogurt (items 25,34 ). Negative items for milk, cheese and yogurt are the sums of the values of items shown in parentheses. As can be seen from Table 7, hypothesis $H_{1}$ is supported: younger, more educated, wealthier and regular diary consumers (Group 1) have significantly lower levels of negative perceptions about milk, cheese and yogurt. In other words, older, less educated, poorer consumers with lower diary food consumption levels (Group 2) have more negative perceptions about dairy products.

Likewise, in order to test our second hypothesis $H_{2}$, consumers are again grouped into two clusters with k-means clustering technique. This time clustering is based on their trust in media and their readiness of sharing such media information with friends. Group 1 included consumers with higher media trust levels for nutrition and health information, and higher readiness levels of sharing such information, while Group 2 included lower levels of trust and readiness. ANOVA statistics between standardized Zscores of trust and sharing level, were significantly different $(p<0.01)$ after iterating 4 times. Table 8 shows the differences of means between the groups and Mann-Whitney $U$ tests results for the positive perception item responses summed for milk (items $2,3,4$ ), cheese (item 17) and yogurt (item $28,29,30,31,32$ ). As can be seen from Table 8 , hypothesis $H_{2}$ is partially supported: consumers with more trust and readiness (Group 1) have significantly higher levels of positive perceptions about milk and yogurt, but not for cheese. These tested outcomes of hypotheses $H_{1}$ and $H_{2}$ are apparently noteworthy for designing marketing communication actions of dairy companies in order to maintain the sustainability of their products.

\section{CONCLUSION}

This study was conducted to examine and analyze how consumer perceptions towards dairy products are developed through information from mass media. The quantitative content analysis of newspapers, TV shows and internet revealed a comprehensive list of mediated issues on dairy products. This list of issues was also investigated qualitatively in three successive focus groups of 18 participants. It is found that both the media content and focus group mentions of dairy issues agree generally. Consumers are exposed to a 
large amount of information from media channels which they usually trust. Consumers accordingly develop their perceptions on issues, which they mainly learn from media information. These mediated issues are further examined with a survey questionnaire of perception statements, which is applied to a sample of 733 from urban population. It is found that positive perceptions were generally stronger than negative ones in dairy consumers' perceptions. Additionally, gender, education level and household income are found to have little impact on dairy consumers' general perceptions. This reveals that media effectively mediates all these issues to the general public regardless of their sociodemographic differences. We can argue that this may be attributed to the "mainstreaming effect of mass media". Finally, when clustered into two groups in terms of age, education, income and dairy product consumption frequency, customers' negative perception levels differ significantly. Younger, more educated, wealthier and regular diary consumers have lower levels of negative perceptions about milk, cheese and yogurt, whereas older, less educated, poorer consumers with lower diary food consumption levels have more negative perceptions. On the other hand, when clustered into two groups in terms of their trust in media and readiness to share information, customer's positive levels of perceptions on milk and yogurt differed significantly. In summary, consumers are exposed to fairly huge amounts on mass media information about dairy products, and these information play an important role on developing and maintaining their perceptions.

This research obviously has certain limitations. A wider sample covering rural population as well as some small cities would apparently be more representative. A semantic and semiotic analysis of media content and focus group discussions could be more exploratory for the psychological and socio-linguistic foundations of these perceptions. Historical dimension is also lacking especially for observing the media content change over time, thus a longitudinal research design would be appropriate in order to understand the change through periods. The effects of social media platforms, such as forums and Facebook groups, may also be another interest of research. Recent literature has shown that social media is a very efficient marketing communication tool for changing human food consumption trends. Additionally, experimental research designs could be very useful how the consumers conceptualize and form their perceptions from certain media content. Apparently, further research is needed to accomplish all these research suggestions.

The list of mediated perceptions and their surveyed mean values provided by this study is important for both producers' and marketers' practices. Public policy makers can also make use of these findings for their public communications campaigns aiming at increasing dairy product consumption for healthier nutrition. These perceptions and their verbal expressions can also be useful for developing proper marketing communication strategies. Industry planners as well as public policy developers may also review this list of perceptions and their respective values for improving their future production policies.

\section{ACKNOWLEDGEMENT}

The data used in this paper is based on our research project supported by The Scientific and Technological Research Council of Turkey (TÜBİTAK), Project no: 114K006.

\section{REFERENCES}
ADA. (2011). Nutrition and You: Trends 2011. Retrieved on 2.2.2015 from http://www.eatrightpro.org/ /media/eatrightpro\%20filesmedia/trends\%20and\%20re views/nutrition\%20and\%20you/where_did_you_hear_that_ada_trends_2011.ashx 
Atabek, G., Atabek, U., \& Bilge, D. (2011). Sağlık Haberlerinde Dönüşüm: 1970-2010 Yılları Arasında Hürriyet Gazetesinde Sağlık Haberleri [Transformation of health news: Health news in Hürriyet newspaper between 1970-2010]. In: Elbek O. (ed.) Kapitalizm Sağlığa Zararlıdır [Capitalism is harmful to your health] (pp. 113-33). HayyKitap, İstanbul.

Ates, H. C., \& Ceylan, M. (2010). Effects of socio-economic factors on the consumption of milk, yoghurt, and cheese: Insights from Turkey. British Food Journal, 112(3), 234250. https://doi.org/10.1108/00070701011029110

Barker, M. E., McNeir, K., Sameer, S., \& Russle, J. (2014). Food, nutrition and slimming messages in British women's magazines, 1950-1998. Journal of Human Nutrition and Dietetics, 27( 2), 124-134. https://doi.org/10.1111/jhn.12076

Batmaz, M. V. (2011). More coverage, less gain: The effects of "political journalism on politics and elections: The Turkish case. Conference on Media, Ekaterinburg, Russian Federation, 14-15 April 2011, 1(1), 263-269.

Bor, Ö. (2014). Economics of Dairy Farming In Turkey. International Journal of Food and Agricultural Economics, 2(4), 49-62.

Bordens, K. S., \& Horowitz, I. A. (2000). Social Psychology. Lawrence Erlbaum, Mahwah NJ.

Bus, A. E. M., \& Worsley, A. (2002). Consumers' sensory and nutritional perceptions of three types of milk. Public Health Nutrition, 6(2), 201-208. https://doi.org/10.1079/PHN2002417

Courtis, J. K. (2002). Preface: Communication, corporate annual reports and perception engineering. Accounting, Auditing \& Accountability Journal Special Issue, 15(4), 444449.

Fallows S. J. (1986). Consumer attitudes to foods and nutrition. Nutrition \& Food Science. https://doi.org/10.1108/eb059416

Fishbein M., \& Ajzen I. (2010). Predicting and Changing Behavior: The Reasoned Action Approach. Psychology Press, New York. https://doi.org/10.4324/9780203838020

Gerbner, G., Gross, L., Morgan, M., \& Signorielli, N. (1980). The "mainstreaming" of America: Violence profile no. 11. Joumal of Communication, 30(3), 10-29. https://doi.org/10.1111/j.1460-2466.1980.tb01987.x

Gezmen-Karadağ, M., \& Türközü, D. (2018) Consumers' Opinions and Use of Food Labels, Nutrition, and Health Claims: Results from Turkey. Journal of Food Products Marketing, 24(3), 280-296. https://doi.org/10.1080/10454446.2017.1266558

Glaser, B. G. (2004). Remodeling grounded theory. The Grounded Theory Review: An International Journal, 4(1), 1-24.

Gracia, A., \& Albisu, L. M. (2001). Food consumption in the European Union: Main determinants and country differences. Agribusiness, 17(4), 469-488. https://doi.org/10.1002/agr.1030

Günden, C., Bilgic, A., Miran, B., \& Karli, B. (2011). A censored system of demand analysis to unpacked and prepackaged milk consumption in Turkey. Qual Quant, 45, 12731290. https://doi.org/10.1007/s11135-011-9501-6

Hatirli, S. A., Ozkan, B., \& Aktas A. R. (2004). Factors affecting fluid milk purchasing sources in Turkey. Food Quality and Preference, 15, 509-515. https://doi.org/10.1016/j.foodqual.2003.11.002

Howard, J. A., \& Sheth, J. N. (1969). The Theory of Buying Behavior. John Willey, New York. 
Online Journal of Communication and Media Technologies, 2019

Hruschka D. J., Schwartz, D., Cobb St. John, D., Picone-Decaro, E., Jenkins, R. A., \& Carey, J. W. (2004). Reliability in coding open-ended data: Lessons learned from HIV behavioral research. Field Methods, 16(3), 307-331. https://doi.org/10.1177/1525822X04266540

Hsu, J. L., \& Liu G. S. (2000). Consumer perceptions of fluid milk advertising in Taiwan. International Journal of Advertising, $19, \quad 471-486$ https://doi.org/10.1080/02650487.2000.11104815

Hundekar, S. G., Appannaiah, H. R., \& Reddy, P. N. (2010). Principles of Marketing. Himalaya Publishing House, Mumbai.

Irvan, S. (1997). Dış Politika ve Basın: Türk Basınındaki Dış Politika Haberlerinin Gündem Belirleme Yaklaşımı Açısından Çözümlenmesi [Foreign policy and the press: Analysis of foreign policy news in the Turkish press from agenda-setting perspective], Unpublished Doctoral Dissertation, Ankara University.

Koç, B., \& Ceylan, M. (2009). Consumer-awareness and information sources on food safety: A case study of Eastern Turkey. Nutrition \& Food Science, 39(6), 643-654. https://doi.org/10.1108/00346650911002977

Konar, N., Haspolat Kaya, I., Dalabasmaz, S., Poyrazoğlu, E. S., \& Artık, N. (2014). Street milk and urban consumers in Turkey: a descriptive study. Journal of Consumer Protection and Food Safety, 9, 23-35. https://doi.org/10.1007/s00003-013-0854-8

Kortge, G. D., \& Okonkwo, P. A. (1993). Perceived value approach to pricing. Industrial Marketing Management, 22(2), 67-160. https://doi.org/10.1016/0019-8501(93)90039-A

Kumar, B., \& Gogoi, M. (2009). Consumers' perception and satisfaction with regard to 'Purabi' in Guwahati: A case study. Journal of Marketing \& Communication, 5(1), 5268.

Lowe, W. (2015). Yoshikoder: Cross-platform multilingual content analysis. Java software version 0.6.5. Retrieved on 10.1.2017 from http://conjugateprior.org/software/ yoshikoder/

McCombs, M. E., \& Shaw, D. L. (1972). The agenda-setting function of mass media. Public Opinion Quarterly, 36(2), 176-187. https://doi.org/10.1086/267990

Millar, K. M., Tomkins, S. M, White, R. P., \& Mepham, T. B. (2002). Consumer attitudes to the use of two dairy technologies. British Food Journal, 104(1), 31-44. https://doi.org/10.1108/00070700210418721

Monroe, K. B. (2012). Price and customer's perceptions of value. In: Smith G. E. (ed.), Advances in Business Marketing and Purchasing, Volume 19: Visionary Pricing: Reflections and Advances in Honor of Dan Nimer (pp. 129-152). Emerald Insight, Bradford. https://doi.org/10.1108/S1069-0964(2012)0000019012

Morrison, J. (2008). International Business: Challenges in a Changing World. Palgrave Macmillan.

Ophuis, P. A. M. O., \& Van Trijp, H. C. M. (1995). Perceived quality: A market driven and consumer oriented approach. Food Quality and Preference, 6, 177-183. https://doi.org/10.1016/0950-3293(94)00028-T

Paraffin, A. S., Zindove, T. J., \& Chimonyo, M. (2017). Household consumption preferences of dairy products and their perceptions of milk safety. Journal of Food Safety, 38(2), 1-8. https://doi.org/10.1111/jfs.12428

Peng, Y., West, G. E., \& Wang, C. (2006). Consumer attitudes and acceptance of CLAenriched dairy products. Canadian Journal of Agricultural Economics, 54, 663-684. https://doi.org/10.1111/j.1744-7976.2006.00072.x 
Ramachandra, K., Chandrashekara, B., \& Shivakumar, S. (2010). Marketing Management. Himalaya Publishing House, Mumbai.

Schacter, D. L., Gilbert, D. T., \& Wegner, D. M. (2011). Psychology (2nd Edition). Worth, New York.

Shanahan, J., \& Morgan, M. (2003). Television and its Viewers: Cultivation Theory and Research. Cambridge University Press.

Sherlekar, S. A., Prasad, K. N., \& Victor, S. J. S. (2010). Principles of Marketing. Himalaya Publishing House, Mumbai.

Tekgüç, H. (2013). Oligopoly and Price Transmission in Turkey's Fluid Milk Market. Agribusiness, 29(3), 293-305. https://doi.org/10.1002/agr.21333

Terin, M, Bilgiç, A., Güler, I. O., \& Yavuz, F. (2014). Türkiye'de Süt Ürünleri Tüketim Harcamalarına Etki Eden Faktörlerin Analizi: Çoklu Heckman Örneklem Seçicilik Sistem Yaklaşımı [Analyzing Factors Affecting Household Milk Products' Expenditures in Turkey: A Multivariate Heckman Sample Selection System Approach]. Tarım Bilimleri Dergisi - Journal of Agricultural Sciences, 21(4), 500515. https://doi.org/10.1501/Tarimbil_0000001353

Tian, Y., \& Robinson, J. D. (2008). Media Use and Health Information Seeking: An Empirical Test of Complementarity Theory. Health Communication, 23(2), 184-190. https://doi.org/10.1080/10410230801968260

Tiryaki, G. Y., \& Akbay, C. (2010). Consumers' fluid milk consumption behaviors in Turkey: an application of multinomial logit model. Qual Quant, 44, 87-98. https://doi.org/10.1007/s11135-008-9182-y

TÜİK. (2018a). Hayvansal Üretim İstatistikleri: 2017 [Animal Products Statistics: 2017]. Retrieved on 11.1.2018 from http://www.tuik.gov.tr/PdfGetir.do?id=27704

TÜİK. (2018b). İllere Göre Süt Üretimi Dağılımı: 2016 [Milk Production Distribution in Provinces: 2016]. Retrieved on 11.1.2018 from http://www.tuik.gov.tr/HbGetir.do?id= $24655 \&$ tb_id $=9$

Uçar, A., Özdoğan, Y. \& Özfer Özçelik, A. (2012). Consumer Attitudes toward Food Consumption and Purchase in Turkey. Ecology of Food and Nutrition, 51(6), 492-504. https://doi.org/10.1080/03670244.2012.705736

Uysal, Ö. K., Miran, B., Bektaş, Z. K., \& Günden, C. (2006). İzmir İlinde Gıda Güvenliğine İlişkin Tüketici Davranışlarının Belirlenmesi Üzerine Bir Araştırma [A study on determining the consumer attitudes to food security: Evidence from Izmir Province]. TÜBITAK Projesi: 103K002.

Walgrave S., Soroka, S., \& Nuytemans, M. (2008) Analysis of media, parliament, and government in Belgium (1993 to 2000). Comparative Political Studies, 41(6), 814-836. https://doi.org/10.1177/0010414006299098

Weatherell, C., Tregear, A., \& Allinson, J. (2003). In search of the concerned consumer: UK public perceptions of food, farming and buying local. Journal of Rural Studies, 19(2), 233-244. https://doi.org/10.1016/S0743-0167(02)00083-9

Wu, J. (2012). Advances in K-means Clustering: A Data Mining Thinking. Heidelberg: Springer. https://doi.org/10.1007/978-3-642-29807-3

Yadavalli, A., \& Jones, K. (2014). Does media influence consumer demand? The case of lean finely textured beef in the United States. Food Policy, 49 Part 1, 219-227. https://doi.org/10.1016/j.foodpol.2014.08.002 
Yüksel, E. (1999). Türkiye’deki Ekonomi Basını Gündemi ve Siyasal Gündem Illişkisi: Özelleştirme Örneğinde Bir Gündem Belirleme Çalışması [The Relationship between economy pages agenda and policy agenda in Turkey: An agenda setting study on privatization issue], Unpublished Doctoral Dissertation, Anadolu University, Eskişehir, Turkey.

Yüksel, E., Kaya, A. Y., Koçak, A., \& Aydın, S. (2013). Türkiye’de Sağlık Konulu Yayıncılık Illkelerinin Belirlenmesi: Kaynak, İleti ve Hedef Kitle Bağlamında Sağllk Konulu Yayınlarin Analizi [Determination of the principles of publication of health issues in Turkey: The Analysis of publication of health issues in the name of source, message, and target audience]. TÜBİTAK Projesi: 109K534.

Zimmerman, W. (2008). Perception of a Difference: The Power in Buying, Marketing and Selling Customer Care. WZA Incorporated, Scottsdale AZ.

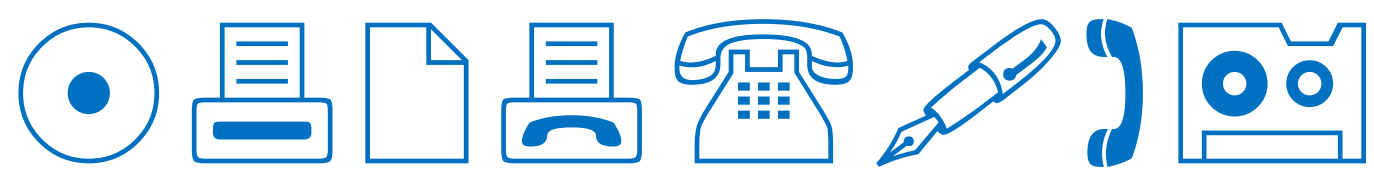

